\title{
Statistical Prediction of Biogas and Methane Yields during Anaerobic digestion Based on the Composition of Lignocellulosic Biomass
}

\begin{abstract}
Agata Stachowiak-Wencek, ${ }^{\mathrm{a}}$ Jan Bocianowski, ${ }^{\mathrm{b}}$ Hanna Waliszewska, ${ }^{\mathrm{c}}$ Sławomir Borysiak, ${ }^{\mathrm{d}}$ Bogusława Waliszewska, ${ }^{\mathrm{a}}$ and Magdalena Zborowska ${ }^{\mathrm{a}}$

In the described study, the relationships between the percentage and structure of selected lignocellulosic components and the efficiency of their anaerobic digestion and the quality of the produced biogas were analyzed. This research included various lignocellulosic raw materials. The biogas efficiency and quality tests were carried out according to DIN standard 38 414-8 (1985) and VDI standard 4630 (2016). Multiple TAPPI standards and the Seifert method were used to determine the chemical composition of the lignocellulose materials. Lignin structure analysis was performed using Fourier transform infrared spectroscopy. Wide-angle X-Ray scattering analysis was used to determine the degree of crystallinity of cellulose. The biogas was positively correlated with $\mathrm{C}=\mathrm{O}$ and the syringyl to guaiacyl ratio, and negatively correlated with the crystalline structure of cellulose, lignin, cellulose, and extractives. In addition, methane was positively correlated with holocellulose and extractives and negatively correlated with the crystalline structure of cellulose, cellulose, substances soluble in $\mathrm{NaOH}$, and the $\mathrm{OH}$ groups. The found independent features accounted for $86.0 \%$ of the biogas variability and $68.0 \%$ of the methane variability.
\end{abstract}

Keywords: Biogas yield; Anaerobic digestion; Methane production; Lignocellulosic biomass; Cellulose; Lignin; Crystallinity of cellulose

Contact information: a: Department of Chemical Wood Technology, Poznań University of Life Sciences, Poznań PL-60637 Poland; b: Department of Mathematical and Statistical Methods, Poznań University of Life Sciences, Poznań PL-60637 Poland; c: Department of Biosystems Engineering, Poznań University of Life Sciences, Poznań PL-60637 Poland; d: Institute of Chemical Technology and Engineering, Poznań University of Technology, Poznań PL-60965 Poland;

* Corresponding author: agata.stachowiak@up.poznan.pl

\section{INTRODUCTION}

The global energy sector currently has to reconcile three trends, i.e., the growing demand for energy, the depletion of natural/fossil fuel resources, and increasingly stringent standards for energy production and environmental protection. The reasons for the need to reduce the use of fossil fuels are discussed in Panahi et al. (2019). In light of EU directive $2108 / 2001$, it is important to increase the use of renewable energy in terms of global energy production. Considering various alternative energy sources, biomass is a highly desirable renewable raw material and can play a significant role in the energy generation sector (Tursi 2019).

Lignocellulosic biomass has a huge energy potential. Nevertheless, it is used to a rather small extent in terms of anaerobic digestion for biogas production. The use of lignocellulosic biomass, e.g., annual and perennial plants, for energy purposes depends on 
its chemical composition and physical properties. The chemical composition of various types of biomasses as well as the changes that they undergo due to anaerobic digestion have been described by various authors (Mulat et al. 2018; Stachowiak-Wencek et al. 2018; Waliszewska et al. 2018; Stachowiak-Wencek 2019a,b; Waliszewska et al. 2019). The limitation on the use of lignocellulosic biomass for the production of biogas seems to be the considerable lignin content, which only slightly decomposes under oxygen-free conditions (Pu et al. 2013; Ragauskas et al. 2014, Theuretzbacher et al. 2015; Mulat et al. 2018).

This is important because maintaining anaerobic conditions is essential to the operation of a biogas plant. However, lignocellulosic biomass is a biological material composed of many components, primarily carbohydrates, which are more readily biodegradable under anaerobic conditions than lignins. However, the effect of their percentage or structure on anaerobic digestion is not well known. The availability of cellulose to microorganisms and the degree of its degradation to glucose play a key role in methane fermentation (Michalska and Ledakowicz 2012). In lignocellulosic raw materials, this availability is difficult because cellulose is surrounded by both hemicelluloses and lignins. Hemicelluloses are short, branched, amorphous five- and six-carbon polymers, and are more susceptible to hydrolysis than cellulose (Castro et al. 1994).

During the fermentation of lignocellulosic biomass, in which there are difficulties in terms of the level of decomposition of high-molecular organic substances, appropriate technological treatment of the charge is often applied. There are several groups of methods that biomass can be subjected to, i.e., mechanical, thermal-pressure, chemical, and biological treatments (Witaszek et al. 2015; Aftab et al. 2018; Kamusoko et al. 2019; Cheah et al. 2020; Tabatabaei et al. 2020a,b). These methods change the chemical composition of the biomass, the structure of the lignins and cellulose, the degree of crystallinity, and the polymerization of cellulose, as well as changes in the physical parameters, e.g., the surface area, size, and volume of the pores ( $\mathrm{Pu}$ et al. 2013). However, the importance of extractives in this process has not been recognized. This issue, briefly described in the literature, is extremely important from the point of view of the possibility of increasing the efficiency of biogas production from lignocellulosic raw materials.

In order to maintain the continuity of biogas plant operations, as well as high economic efficiency, it is necessary to use various raw materials in the fermentation process. In the management of a biogas plant, it may be helpful to quickly and reliably estimate the yield potential of biogas and methane based on the use of developed empirical models. The basic information enabling the development of empirical models is data on the chemical composition of the biomass and experimental values of the biogas yield (Dandikas et al. 2014). In the literature, numerous empirical models designed to estimate various raw materials can be found.

Amon et al. (2007) developed the methane energy value model based on maize silage. They estimated the results of digestive experiments in terms of methane recovery from crude protein, crude fat, cellulose, and hemicellulose. In turn, Triolo et al. (2011) developed a model for energy crops, e.g., grass, maize, and straw, or for manure. Their research showed that the potential of biomethane primarily depended on the lignin content. A statistical model to predict the potential of biomethane from lignocellulosic materials was also developed by Thomsen et al. (2014). The full model for predicting biomethane potential, includes the four biomass components, i.e., cellulose, hemicellulose, lignin, and residuals. Correlation between the biogas yield and the chemical compositions of energy crops was also discussed by Dandikas et al. (2014). They found that the biogas yield was 
significantly negatively correlated with acid detergent lignins. In addition, they showed that apart from lignins, only hemicelluloses seemed to cause a significant difference in the biogas yield.

The methane energy models require further validation and refinement, which is of great practical importance. Determining the potential biogas yield from different types of biomasses can help manage biogas plant more efficiently. Moreover, previous publications did not include pretreated raw materials. The pretreatment methods are designed to increase the susceptibility of the raw materials to degradation as well as the fermentation efficiency and are increasingly used.

The aim of this study was to develop models that allow the estimation of the biogas efficiency and its methane content, based on the chemical composition of the raw material.

\section{EXPERIMENTAL}

\section{Materials}

Three species of miscanthus (Miscanthus x giganteus, Miscanthus sacchariflorus, and Miscanthus sinensis), two varieties of sorghum (Sorghum bicolor and Sorghum saccharatum), two varieties of poplar [Poplar (AF16), Poplar (HYBR.275)], and maize straw were used to develop biogas and methane yield models. All the raw materials were collected in Poland. The miscanthus and sorghum were harvested in two periods, during and after vegetation. The poplar varieties included in the research came from two different plantations. The plantation poplar wood and corn straw were chemically pretreated. Treatments with $\mathrm{H}_{2} \mathrm{SO}_{4}$ and $\mathrm{NaOH}$ were applied according to the method described by Stachowiak-Wencek et al. (2019a).

\section{Methods}

Anaerobic digestion

Anaerobic digestion was conducted under the procedure described in DIN standard 38 414-8 (1985) and VDI standard 4630 (2016). It was performed in a 21-chamber biofermentor (Department of Biosystems Engineering, Poznań University of Life Sciences, Poznań, Poland) whose schematic is presented in Lewicki et al. (2013). Glass chambers (capacity $2 \mathrm{dm}^{3}$ ) with the material were placed in water at a temperature of $39{ }^{\circ} \mathrm{C} \pm 1{ }^{\circ} \mathrm{C}$ in mesophilic conditions. The samples were tested in triplicate.

The material was treated with an inoculum, which was taken from an agricultural biogas plant. The following properties of the inoculum were determined as follows: the chemical composition was determined according to TAPPI methods such as for samples of raw material [TAPPI T9 wd-75 (2015), TAPPI T $223 \mathrm{~cm}-01$ (2001), the Seifert method (Seifert 1956), TAPPI T 222 om-06 (2006), TAPPI T 204 cm-07 (2007), and TAPPI T 212 om-02 (2007)], the pH was determined according to PN-EN ISO standard 9963-1 (2001), the ammonium nitrogen concentration was determined according to standard PN-73/C04576/02 (1973), the dry matter content was determined according to PN-EN standard 12879 (2002), and the mineral substances were determined according to TAPPI standard T 211 om-07 (2007). The inoculum contained the following: $29.7 \%$ holocellulose, $32.4 \%$ cellulose, $6.6 \%$ pentosans, $48.9 \%$ lignins, $5.8 \%$ extractives, $64.9 \%$ substances soluble in $1 \% \mathrm{NaOH}, 8.8 \%$ substances soluble in cold water, and $13.9 \%$ substances soluble in hot water. The concentration of ammonium nitrogen was lower than $2.5 \mathrm{~g} / \mathrm{dm}^{3}$. The dry matter 
content in the aqueous inoculum solution amounted to approximately $2.7 \%$ to $2.9 \%$, of which approximately $28 \%$ to $30 \%$ was minerals. The $\mathrm{pH}$ was approximately 7 .

The digested residue was divided using a Büchner funnel into two fractions, i.e., solid and liquid. The solid fraction of digested pulp was initially dried in a drying apparatus at a temperature of $50{ }^{\circ} \mathrm{C}$, and conditioning was later continued for $10 \mathrm{~d}$ under laboratory conditions (at temperatures of $22{ }^{\circ} \mathrm{C} \pm 1{ }^{\circ} \mathrm{C}$ ). Digested pulp prepared in this way was then chemically analyzed. The biogas yield and methane content are shown in Table 1.

Table 1. Biogas Yield from the Analyzed Types of Lignocellulosic Biomass and its Methane Content

\begin{tabular}{|c|c|c|c|}
\hline \multicolumn{2}{|c|}{ Lignocellulosic Biomass } & \multirow{2}{*}{$\begin{array}{c}\text { Biogas Efficiency }\left(\mathrm{m}^{3} / \mathrm{Mg}\right) \\
373.6(18.5)\end{array}$} & \multirow{2}{*}{$\begin{array}{c}\text { Methane Content (\%) } \\
53.7\end{array}$} \\
\hline Miccanthuc y riaanteuc & during ${ }^{* * *}$ & & \\
\hline Minsearitins x gryamineus & after ${ }^{\star * \star *}$ & $404.8(11.1)$ & 52.2 \\
\hline \multirow{2}{*}{ Miscanthus sacchariflorus } & during ${ }^{\star \star *}$ & $434.8(10.8)$ & 53.1 \\
\hline & after $^{\star \star \star *}$ & $462.0(0.3)$ & 47.4 \\
\hline \multirow{2}{*}{ Miscanthus sinensis } & during ${ }^{\star \star \star}$ & $410.9(12.2)$ & 52.9 \\
\hline & $\operatorname{after}^{\star * \star *}$ & $481.6(6.8)$ & 48.4 \\
\hline \multirow{2}{*}{ Sorghum bicolor } & during $^{\star \star *}$ & $689.1(16.4)$ & 51.2 \\
\hline & after ${ }^{\star * * *}$ & $504.3(10.3)$ & 51.2 \\
\hline \multirow{2}{*}{ Sorghum saccharatum } & during $^{* * *}$ & $592.0(54.2)$ & 52.1 \\
\hline & after $^{\star \star \star *}$ & $519.3(8.8)$ & 51.6 \\
\hline \multirow{5}{*}{ Poplar (AF16) } & control & $279.1(14.7)$ & 56.5 \\
\hline & $1 \% \mathrm{NaOH}$ & $350.0(6.7)$ & 46.5 \\
\hline & $3 \% \mathrm{NaOH}$ & $291.7(17.0)$ & 46.5 \\
\hline & $3 \% \mathrm{H}_{2} \mathrm{SO}_{4}$ & $68.1(17.6)$ & 18.9 \\
\hline & $7 \% \mathrm{H}_{2} \mathrm{SO}_{4}$ & $51.3(6.3)$ & 0.0 \\
\hline \multirow{5}{*}{ Poplar (HYBR.275) } & control & $397.8(5.8)$ & 53.6 \\
\hline & $1 \% \mathrm{NaOH}$ & $351.2(17.1)$ & 45.9 \\
\hline & $3 \% \mathrm{NaOH}$ & $326.8(8.5)$ & 44.4 \\
\hline & $3 \% \mathrm{H}_{2} \mathrm{SO}_{4}$ & $100.5(11.8)$ & 26.5 \\
\hline & $7 \% \mathrm{H}_{2} \mathrm{SO}_{4}$ & $88.7(5.9)$ & 0.8 \\
\hline \multirow{5}{*}{ Corn straw } & control & $455.0(13.8)$ & 52.0 \\
\hline & $1 \% \mathrm{NaOH}$ & $496.0(5.7)$ & 51.0 \\
\hline & $3 \% \mathrm{NaOH}$ & $340.0(12.1)$ & 58.0 \\
\hline & $3 \% \mathrm{H}_{2} \mathrm{SO}_{4}$ & $195.0(10.4)$ & 38.0 \\
\hline & $7 \% \mathrm{H}_{2} \mathrm{SO}_{4}$ & $111.0(14.2)$ & 50.0 \\
\hline $\begin{array}{l}{ }_{* \star *} \text { During the vegetation } \\
{ }^{* \star * *} \text { After the vegetation } \\
{ }^{* * \star *} \text { Standard deviation }\end{array}$ & & & \\
\hline
\end{tabular}


Table 2. Chemical Composition of the Tested Types of Lignocellulosic Biomass

\begin{tabular}{|c|c|c|c|c|c|c|c|}
\hline \multicolumn{2}{|c|}{ Lignocellulosic Biomass } & $\begin{array}{l}\text { Lignin } \\
(\%)\end{array}$ & $\begin{array}{l}\text { Holocellulose } \\
(\%)\end{array}$ & $\begin{array}{c}\text { Cellulose } \\
(\%)\end{array}$ & $\begin{array}{c}\text { Pentosans } \\
(\%)\end{array}$ & $\begin{array}{c}\text { Extractives } \\
(\%)\end{array}$ & $\begin{array}{c}\mathrm{NaOH} \\
(\%)\end{array}$ \\
\hline \multirow{2}{*}{$\begin{array}{l}\text { Miscanthus } \\
\text { x giganteus }\end{array}$} & during ${ }^{\star * *}$ & $\begin{array}{c}17.9 \\
(0.92)^{\star \star}\end{array}$ & $74.0(0.25)$ & $\begin{array}{c}45.1 \\
(0.31)^{*}\end{array}$ & $24.0(0.38)$ & $10.6(1.12)$ & $\begin{array}{c}43.3 \\
(0.28)\end{array}$ \\
\hline & after ${ }^{\star \star \star \star}$ & $\begin{array}{c}24.5 \\
(0.14)^{\star *}\end{array}$ & $82.7(0.20)$ & $\begin{array}{c}46.8 \\
(0.62)^{*}\end{array}$ & $23.7(0.38)$ & $2.9(0.05)$ & $\begin{array}{c}29.8 \\
(1.12)\end{array}$ \\
\hline \multirow{2}{*}{$\begin{array}{c}\text { Miscanthus } \\
\text { sacchariflorus }\end{array}$} & during $* * *$ & $\begin{array}{c}18.4 \\
(0.09)^{\star \star}\end{array}$ & $72.0(1.19)$ & $\begin{array}{c}40.3 \\
(0.37)^{*}\end{array}$ & $24.4(0.16)$ & $13.3(0.13)$ & $\begin{array}{c}47.8 \\
(0.65)\end{array}$ \\
\hline & after ${ }^{\star \star \star *}$ & $\begin{array}{c}20.0 \\
(0.02)^{\star *}\end{array}$ & $70.0(0.43)$ & $\begin{array}{c}44.8 \\
(0.19)^{*}\end{array}$ & $24.7(0.26)$ & $2.9(0.41)$ & $\begin{array}{c}35.6 \\
(0.13) \\
\end{array}$ \\
\hline \multirow{2}{*}{$\begin{array}{l}\text { Miscanthus } \\
\text { sinensis }\end{array}$} & during $* \star \star$ & $\begin{array}{c}17.9 \\
(0.20)^{\star \star}\end{array}$ & $74.0(1.14)$ & $\begin{array}{c}41.3 \\
(0.31)^{*}\end{array}$ & $23.9(0.17)$ & $10.3(2.46)$ & $\begin{array}{c}45.3 \\
(0.20) \\
\end{array}$ \\
\hline & after ${ }^{\star \star \star *}$ & $\begin{array}{c}19.1 \\
(0.25)^{\star *}\end{array}$ & $69.1(0.17)$ & $\begin{array}{c}44.6 \\
(0.14)^{*}\end{array}$ & $24.2(0.37)$ & $3.5(0.57)$ & $\begin{array}{c}34.5 \\
(0.43)\end{array}$ \\
\hline \multirow{2}{*}{$\begin{array}{l}\text { Sorghum } \\
\text { bicolor }\end{array}$} & during $* \star \star$ & $\begin{array}{c}15.4 \\
(0.17)^{* *}\end{array}$ & $66.5(0.87)$ & $\begin{array}{c}42.6 \\
(1.83)^{*}\end{array}$ & $24.2(0.30)$ & $9.6(2.35)$ & $\begin{array}{l}(0.70) \\
(0.25)\end{array}$ \\
\hline & after ${ }^{\star \star * *}$ & $\begin{array}{c}16.9 \\
(0.06)^{\star \star}\end{array}$ & $65.3(0.67)$ & $\begin{array}{c}38.4 \\
(0.55)^{*}\end{array}$ & $20.9(1.50)$ & $38.5(2.23)$ & $\begin{array}{c}64.4 \\
(0.09)\end{array}$ \\
\hline \multirow{2}{*}{$\begin{array}{c}\text { Sorghum } \\
\text { saccharatum }\end{array}$} & during ${ }^{* \star *}$ & $\begin{array}{c}14.5 \\
(0.08)^{* *}\end{array}$ & $70.5(1.58)$ & $\begin{array}{c}39.9 \\
(0.94)^{*}\end{array}$ & $25.8(1.05)$ & $14.4(1.99)$ & $\begin{array}{c}50.4 \\
(0.15) \\
\end{array}$ \\
\hline & after ${ }^{\star \star \star *}$ & $\begin{array}{c}16.6 \\
(0.39)^{* *}\end{array}$ & $63.4(0.58)$ & $\begin{array}{c}41.3 \\
(2.00)^{*}\end{array}$ & $24.7(0.19)$ & $11.5(0.64)$ & $\begin{array}{c}48.7 \\
(0.25) \\
\end{array}$ \\
\hline \multirow{5}{*}{$\begin{array}{l}\text { Poplar } \\
\text { (AF16) }\end{array}$} & control & $\begin{array}{c}24.9 \\
(0.11)\end{array}$ & $74.8(0.07)$ & $\begin{array}{l}40.1 \\
(0.17)\end{array}$ & $22.3(0.45)$ & $2.9(0.24)$ & $\begin{array}{c}24.1 \\
(0.25)\end{array}$ \\
\hline & $1 \% \mathrm{NaOH}$ & $\begin{array}{c}24.7 \\
(0.12) \\
\end{array}$ & $70.9(0.26)$ & $\begin{array}{c}48.9 \\
(1.15)\end{array}$ & $21.8(0.28)$ & $1.0(0.06)$ & $\begin{array}{c}6.8 \\
(0.19) \\
\end{array}$ \\
\hline & $3 \% \mathrm{NaOH}$ & $\begin{array}{l}25.5 \\
(0.35)\end{array}$ & $71.5(0.22)$ & $\begin{array}{l}53.2 \\
(0.56)\end{array}$ & $18.4(0.46)$ & $0.8(0.08)$ & $\begin{array}{c}3.1 \\
(0.06)\end{array}$ \\
\hline & $3 \% \mathrm{H}_{2} \mathrm{SO}_{4}$ & $\begin{array}{c}31.1 \\
(0.22)\end{array}$ & $64.7(0.33)$ & $\begin{array}{c}52.6 \\
(0.60) \\
\end{array}$ & $14.4(0.54)$ & $2.8(0.08)$ & $\begin{array}{c}26.0 \\
(0.27) \\
\end{array}$ \\
\hline & $7 \% \mathrm{H}_{2} \mathrm{SO}_{4}$ & $\begin{array}{c}33.2 \\
(1.07)\end{array}$ & $64.6(0.28)$ & $\begin{array}{l}56.1 \\
(0.40)\end{array}$ & $10.1(0.18)$ & $3.0(0.49)$ & $\begin{array}{c}22.2 \\
(0.38)\end{array}$ \\
\hline \multirow{5}{*}{$\begin{array}{c}\text { Poplar } \\
\text { (HYBR.275) }\end{array}$} & control & $\begin{array}{c}21.9 \\
(0.39)\end{array}$ & $78.2(1.14)$ & $\begin{array}{c}46.2 \\
(0.95)\end{array}$ & $21.4(0.55)$ & $2.1(0.39)$ & $\begin{array}{c}21.3 \\
(0.16)\end{array}$ \\
\hline & $1 \% \mathrm{NaOH}$ & $\begin{array}{c}20.4 \\
(0.16)\end{array}$ & $75.4(2.09)$ & $\begin{array}{c}56.8 \\
(1.37)\end{array}$ & $21.5(0.30)$ & $0.9(0.20)$ & $\begin{array}{c}4.0 \\
(0.19)\end{array}$ \\
\hline & $3 \% \mathrm{NaOH}$ & $\begin{array}{c}20.1 \\
(0.18)\end{array}$ & $75.4(3.63)$ & $\begin{array}{l}57.7 \\
(0.23)\end{array}$ & $20.3(0.41)$ & $0.8(0.19)$ & $\begin{array}{c}3.7 \\
(0.19)\end{array}$ \\
\hline & $3 \% \mathrm{H}_{2} \mathrm{SO}_{4}$ & $\begin{array}{c}26.7 \\
(1.25)\end{array}$ & $69.0(0.21)$ & $\begin{array}{c}58.2 \\
(0.62) \\
\end{array}$ & $11.4(0.39)$ & $3.1(0.31)$ & $\begin{array}{c}27.0 \\
(0.03)\end{array}$ \\
\hline & $7 \% \mathrm{H}_{2} \mathrm{SO}_{4}$ & $\begin{array}{l}28.3 \\
(0.14)\end{array}$ & $70.0(0.19)$ & $\begin{array}{c}62.4 \\
(0.33)\end{array}$ & $6.9(0.20)$ & $3.0(0.23)$ & $\begin{array}{c}23.8 \\
(0.22)\end{array}$ \\
\hline \multirow{5}{*}{ Corn straw } & control & $\begin{array}{c}17.9 \\
(0.22)\end{array}$ & $66.1(0.70)$ & $\begin{array}{c}38.3 \\
(0.14)\end{array}$ & $31.1(0.84)$ & $7.3(0.61)$ & $\begin{array}{c}48.8 \\
(0.30) \\
\end{array}$ \\
\hline & $1 \% \mathrm{NaOH}$ & $\begin{array}{c}3.8 \\
(0.36)\end{array}$ & $89.9(0.15)$ & $\begin{array}{c}56.3 \\
(0.11)\end{array}$ & $37.0(1.65)$ & $1.97(0.11)$ & $\begin{array}{c}13.8 \\
(0.12)\end{array}$ \\
\hline & $3 \% \mathrm{NaOH}$ & $\begin{array}{c}2.1 \\
(0.07)\end{array}$ & $94.8(0.17)$ & $\begin{array}{c}64.7 \\
(0.53)\end{array}$ & $28.9(0.13)$ & $1.4(0.03)$ & $\begin{array}{c}3.6 \\
(0.12)\end{array}$ \\
\hline & $3 \% \mathrm{H}_{2} \mathrm{SO}_{4}$ & $\begin{array}{c}25.7 \\
(0.40)\end{array}$ & $76.2(0.69)$ & $\begin{array}{c}64.8 \\
(0.35)\end{array}$ & $12.1(0.42)$ & $7.8(1.54)$ & $\begin{array}{c}40.8 \\
(0.66)\end{array}$ \\
\hline & $7 \% \mathrm{H}_{2} \mathrm{SO}_{4}$ & $\begin{array}{c}27.0 \\
(0.17)\end{array}$ & $75.6(0.06)$ & $\begin{array}{c}67.4 \\
(0.08)\end{array}$ & $8.0(0.30)$ & $9.3(1.22)$ & $\begin{array}{c}41.7 \\
(0.28)\end{array}$ \\
\hline
\end{tabular}

* Results have been published in Waliszewska et al. (2018); ** ibid. (2019);

${ }^{* * *}$ During the vegetation; ${ }^{* * * *}$ After the vegetation; ${ }^{* * \star *}$ Standard deviation in brackets 


\section{Gravimetric method}

The raw materials were ground in a laboratory mill (Pulverisette 15). The holocellulose, cellulose, pentosans, and lignin contents were determined according to TAPPI standard T9 wd-75 (2015), the Seifert method (Seifert 1956), TAPPI standard T $223 \mathrm{~cm}-01$ (2001), and TAPPI standard T $222 \mathrm{om}-06$ (2006), respectively. The extractive substances and the substances soluble in $1 \% \mathrm{NaOH}$ were analyzed according to TAPPI standard T 204 cm-07 (2007) and TAPPI standard T 212 om-02 (2007), respectively. All analyses were repeated three times for each examined sample set. Table 2 presents the chemical composition of the tested types of lignocellulosic biomass.

\section{Fourier transform infrared spectra (FTIR), X-ray diffraction, and lignin acetylation}

The structure spectroscopy analysis was performed via FTIR. The FTIR spectra of the researched materials were recorded with an Alpha FTIR spectrometer (Bruker Optics $\mathrm{GmbH}$, Ettlingen, Germany). These measurements were performed on the pellets obtained during the homogenization of approximately $200 \mathrm{mg}$ of anhydrous potassium bromide $(\mathrm{KBr})$ with $2 \mathrm{mg}$ of the investigated material, which was subsequently pressed under 10 $\mathrm{MPa}$ pressure. During the measurements, the pellets were scanned within the range of 4000 to $400 \mathrm{~cm}^{-1}$ with a resolution of $4 \mathrm{~cm}^{-1}$. All FTIR spectra were performed three times and particular indicators were determined based on their average.

Fourier transform infrared spectroscopy absorbance graphs were used to calculate the content of the carbonyl groups $(\mathrm{C}=\mathrm{O}, \mathrm{A} 1710 / \mathrm{A} 1510)$, the numerical relations between the syringyl and guaiacyl monomers (S/G, A1325/A1267), and the ratio of aliphatic to aromatic rings (Al/Ar, A2930/A1510) (Fan et al. 2012; Sandford et al. 2013).

The crystallinity of the cellulose was analyzed using the averages of the wide-angle $\mathrm{X}$-ray scattering (WAXS) analysis using $\mathrm{Cu} \mathrm{K} \alpha$ radiation at $30 \mathrm{kV}$ and $25 \mathrm{~mA}$ anode excitation. The X-ray diffraction pattern was recorded for the angles from the range of $2 \Theta$ $=10^{\circ}$ to $30^{\circ}$ in the step of $0.04^{\circ} / 3 \mathrm{~s}$. The diffraction pattern showed three peaks at $2 \Theta=$ $15^{\circ}, 17^{\circ}$, and $22.7^{\circ}$, which were assigned to cellulose. Deconvolution of the peaks was performed via the method proposed by Hindeleh and Johnson (1971), which was improved and programmed by Rabiej (1991). After separation of the X-ray diffraction lines, the crystallinity index $\left(\mathrm{C}_{\mathrm{r}} \mathrm{I}\right)$ of the wood after chemical treatment was calculated by comparison of the areas under the crystalline peaks and the amorphous curve, as shown in Eq. 1,

$$
C_{r} I=\left(\frac{P_{K}}{P_{A}+P_{K}}\right) \cdot 100[\text { in \%] }
$$

where $\mathrm{P}_{\mathrm{A}}$ is the area of the amorphous part, $P_{\mathrm{K}}$ is the total area of the maxima coming from the crystalline part, and $\mathrm{C}_{\mathrm{r}} \mathrm{I}$ is the degree of crystallinity of the repeat $(\%)$.

Determination of the hydroxyl $(\mathrm{OH})$ groups in the lignins was performed via acetylation, according to Lin and Dence (1992).

The results of the FTIR analysis $(\mathrm{C}=\mathrm{O}, \mathrm{S} / \mathrm{G}$, and $\mathrm{Al} / \mathrm{Ar})$, the determination of hydroxyl groups $(\mathrm{OH})$, and the X-ray diffraction are presented in Table 3.

\section{Statistical analysis}

The normality of the distributions for the studied traits, i.e., biogas, methane, crystalline structure of cellulose, lignins, holocellulose, cellulose, pentosans, extractives, soluble in $1 \% \mathrm{NaOH}, \mathrm{OH}, \mathrm{C}=\mathrm{O}, \mathrm{S}$ to $\mathrm{G}$ ratio, and $\mathrm{Al}$ to Ar ratio), were tested using ShapiroWilk's normality test (Shapiro and Wilk 1965). In addition, a multivariate analysis of variance (MANOVA) was performed. 
Table 3. $\mathrm{OH}$ Groups, $\mathrm{C}=\mathrm{O}$ Groups, Syringyl to Guaiacyl Ratio (S/G), Aliphatic to Aromatic Ratio (Al/Ar), and the Degree of Crystalline of Cellulose in the Tested Raw Materials

\begin{tabular}{|c|c|c|c|c|c|c|}
\hline \multicolumn{2}{|c|}{ Lignocellulosic Biomass } & $\mathrm{OH}(\%)$ & $\mathrm{C}=\mathrm{O}$ & $S$ to $G$ & Al to $\mathrm{Ar}$ & Crystalline Structure \\
\hline \multirow{2}{*}{$\begin{array}{l}\text { Miscanthus } \\
\text { x giganteus }\end{array}$} & during ${ }^{\star \star \star}$ & 0.49 & 1.07 & $0.59^{* *}$ & $0.54^{* *}$ & $61.0^{*}$ \\
\hline & after $^{* \star * \star}$ & 0.74 & 0.80 & $0.66^{* *}$ & $0.47^{* *}$ & $64.0^{*}$ \\
\hline \multirow{2}{*}{$\begin{array}{c}\text { Miscanthus } \\
\text { sacchariflorus }\end{array}$} & during ${ }^{\star * *}$ & 0.55 & 1.00 & $0.53^{\star *}$ & $0.99^{* *}$ & $60.0^{*}$ \\
\hline & after ${ }^{\star \star \star \star}$ & 0.63 & 0.81 & $0.65^{\star \star}$ & $0.85^{\star \star}$ & $58.0^{*}$ \\
\hline \multirow{2}{*}{$\begin{array}{l}\text { Miscanthus } \\
\text { sinensis }\end{array}$} & during $^{\star \star *}$ & 0.46 & 1.07 & $0.38^{\star *}$ & $0.83^{\star *}$ & $63.0^{*}$ \\
\hline & after ${ }^{* * * *}$ & 0.55 & 1.07 & $0.49^{* *}$ & $0.61^{* *}$ & $62.0^{*}$ \\
\hline \multirow{2}{*}{$\begin{array}{c}\text { Sorghum } \\
\text { bicolor }\end{array}$} & during $^{* \star *}$ & 0.63 & 0.90 & $0.59^{* *}$ & $0.74^{* *}$ & $58.0^{*}$ \\
\hline & after $^{\star * * *}$ & 0.65 & 1.02 & $0.64^{* *}$ & $0.73^{\star *}$ & $59.0^{*}$ \\
\hline \multirow{2}{*}{$\begin{array}{c}\text { Sorghum } \\
\text { saccharatum }\end{array}$} & during ${ }^{\star * *}$ & 0.39 & 0.89 & $0.57^{\star \star}$ & $0.61^{* \star}$ & $54.0^{*}$ \\
\hline & after $^{* * * *}$ & 0.29 & 0.86 & $0.61^{* *}$ & $0.54^{\star \star}$ & $55.0^{*}$ \\
\hline \multirow{5}{*}{ Poplar (AF16) } & control & 0.74 & 0.36 & 0.85 & 0.50 & 62.0 \\
\hline & $1 \% \mathrm{NaOH}$ & 0.74 & 0.30 & 0.96 & 0.50 & 63.0 \\
\hline & $3 \% \mathrm{NaOH}$ & 0.75 & 0.23 & 1.06 & 0.48 & 69.0 \\
\hline & $3 \% \mathrm{H}_{2} \mathrm{SO}_{4}$ & 0.77 & 0.38 & 0.84 & 0.51 & 65.0 \\
\hline & $7 \% \mathrm{H}_{2} \mathrm{SO}_{4}$ & 0.77 & 0.39 & 0.83 & 0.51 & 65.0 \\
\hline \multirow{5}{*}{ Poplar (HYBR.275) } & Control & 0.79 & 0.45 & 0.77 & 0.49 & 62.0 \\
\hline & $1 \% \mathrm{NaOH}$ & 0.75 & 0.28 & 0.97 & 0.48 & 64.0 \\
\hline & $3 \% \mathrm{NaOH}$ & 0.76 & 0.24 & 1.03 & 0.48 & 70.0 \\
\hline & $3 \% \mathrm{H}_{2} \mathrm{SO}_{4}$ & 0.78 & 0.44 & 0.76 & 0.48 & 66.0 \\
\hline & $7 \% \mathrm{H}_{2} \mathrm{SO}_{4}$ & 0.78 & 0.44 & 0.76 & 0.49 & 67.0 \\
\hline \multirow{5}{*}{ Corn straw } & control & 0.67 & 0.78 & 0.50 & 0.43 & 55.0 \\
\hline & $1 \% \mathrm{NaOH}$ & 0.92 & 0.61 & 0.69 & 0.54 & 56.0 \\
\hline & $3 \% \mathrm{NaOH}$ & 1.18 & 0.44 & 0.07 & 0.24 & 59.0 \\
\hline & $3 \% \mathrm{H}_{2} \mathrm{SO}_{4}$ & 0.66 & 0.74 & 0.50 & 0.43 & 55.0 \\
\hline & $7 \% \mathrm{H}_{2} \mathrm{SO}_{4}$ & 0.66 & 0.73 & 0.57 & 0.42 & 54.0 \\
\hline \multicolumn{7}{|c|}{$\begin{array}{l}{ }^{*} \text { the results have been published in Waliszewska et al. (2018) } \\
{ }^{* *} \text { the results have been published in Waliszewska et al. (2019) } \\
{ }^{* * *} \text { during the vegetation } \\
{ }^{* * \star \star} \text { after the vegetation }\end{array}$} \\
\hline
\end{tabular}

Next, one-way analyses of variance (ANOVA) were carried out to determine the effects of the raw materials on the variability of the examined traits, for each trait independently. The correlations between all observed traits were assessed on the basis of Pearson's correlation. The analysis of the relationships between biogas and methane (independently) and the other examined traits (lignins, holocellulose, cellulose, crystalline structure of cellulose, pentosans, extractives, soluble in $1 \% \mathrm{NaOH}, \mathrm{OH}, \mathrm{C}=\mathrm{O}, \mathrm{S}$ to $\mathrm{G}$ ratio, and $\mathrm{Al}$ to Ar ratio) were carried out with the use of the multivariate regression analysis. The selection of traits was done by using a forward-backward stepwise, multiple linear regression with a probability into and out of the model of 0.05 . The analyses were 
conducted for biogas and methane separately. The coefficients of determination were used to measure how the model fit the data. All the analyses were conducted using the GenStat (Version 18, VSN International, Hemel Hempstead, United Kingdom) statistical software package.

\section{RESULTS AND DISCUSSION}

\section{Biogas Yield Potential and the Chemical Composition}

The tested raw materials were characterized by the differentiated biogas yield, which varied widely, i.e., from 51.3 to $689.1 \mathrm{~m}^{3} / \mathrm{mg}$ (Table 1). In addition, the methane content in the obtained biogas significantly differed, i.e., from $0 \%$ to $56.5 \%$ (as shown in Table 1). The visible different chemical composition of the analyzed biomasses deserves attention (as shown in Table 2). Greater percentage differences were detected for lignins, pentosans, extractives, and substances soluble in $1 \% \mathrm{NaOH}$. The lignin content ranged from $2.1 \%$ to $33.2 \%$, the pentosan content ranged from $6.9 \%$ to $37.0 \%$, the extractive content ranged from $0.8 \%$ to $38.5 \%$, and the content of the substances soluble in $1 \% \mathrm{NaOH}$ ranged from $3.1 \%$ and $64.4 \%$. For that last chemical component, i.e., substances soluble in $1 \% \mathrm{NaOH}$, the differentiation was the biggest. Smaller differences were stated for holocellulose and cellulose, i.e., $63.4 \%$ to $94.8 \%$ and $38.3 \%$ to $67.4 \%$, respectively. In Table 3, the structural feature of the chemical components of wood are presented. The hydroxyl and carboxyl groups content ranged from 0.29 to 1.18 and from 0.23 to 1.07 , respectively. In each tested material, the percentage of crystal structure in cellulose was greater than $50 \%$.

\section{Correlations Between the Observed Traits}

The results of the MANOVA indicated that all the raw materials were significantly different with regards to all the 13 quantitative traits (Wilk's $\lambda=0.00000006316 ; F_{7 ; 67}=$ 51.30; and $p$-value less than 0.0001). The results of the analysis of variance for the 13 quantitative traits showed variability of the tested raw materials at a significance level of $\alpha$ $=0.01$ (Table 4).

The correlation analysis indicated statistically significant correlation coefficients for 57 out of 78 of the coefficients. A total of 24 out of 57 significantly correlated pairs of traits were characterized by positive correlation coefficients (as shown in Table 5 and Fig. 1). The biogas yield showed positive correlation coefficients with seven traits. The most important were the correlation coefficients of the biogas yield with the percentage of pentosans and in terms of the structural features, the $\mathrm{C}=\mathrm{O}$ groups content. This is confirmed by the fact that the carbonyl groups identified via FTIR are assigned to the ketone, ester, or carboxylic groups in the hemicelluloses and not from the lignins (Zhang et al. 2019). In addition, methane showed positive correlation coefficients with six traits, with the strongest trait being the percentage of pentosans, with the content of carboxyl groups only being slightly lower. It is worth noting there were strong positive correlations between the amount of methane and the extractives content, and the substances soluble in a $1 \% \mathrm{NaOH}$ solution. 
Table 4. Mean Squares from Analysis of Variance for Observed Traits

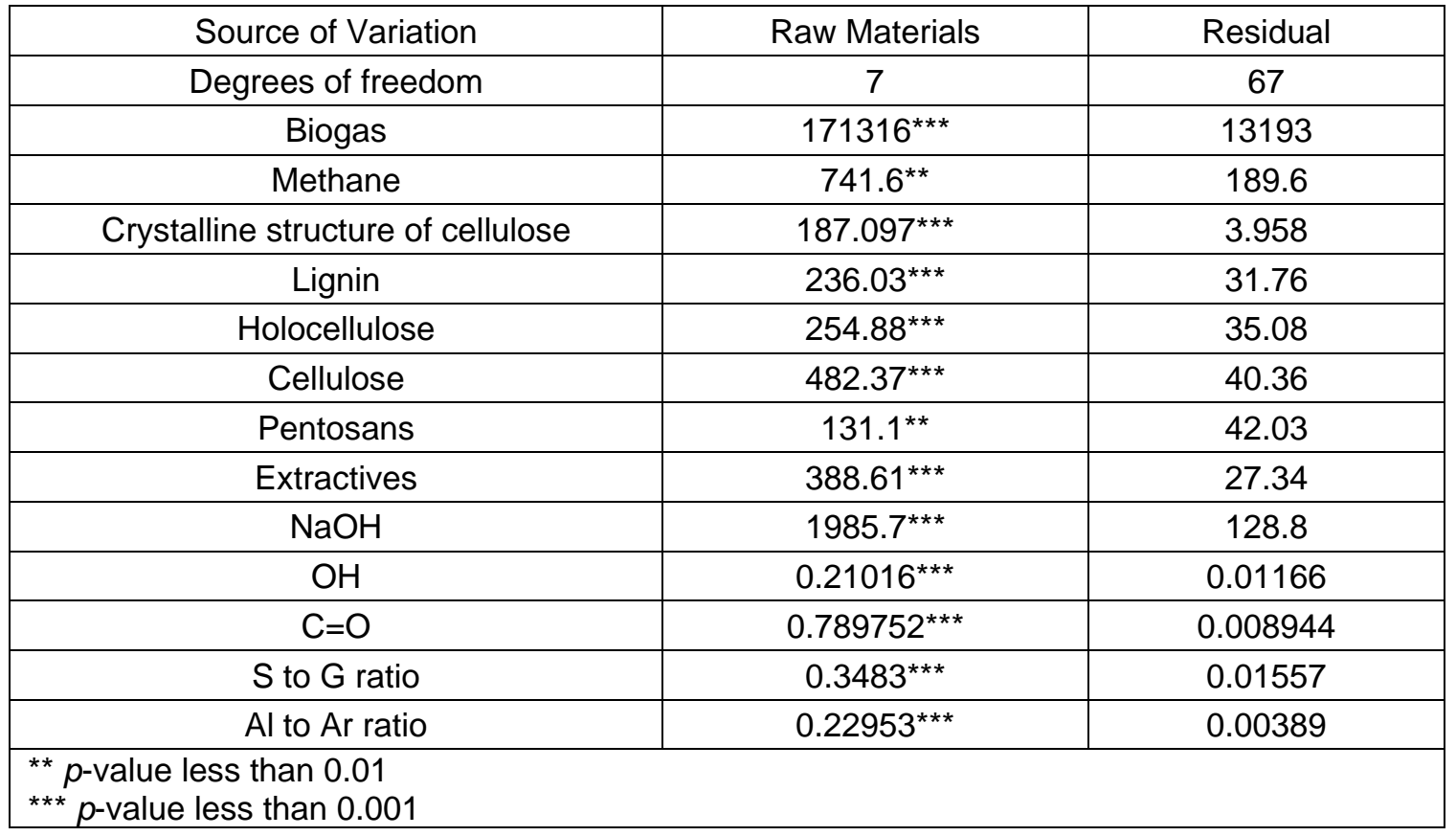

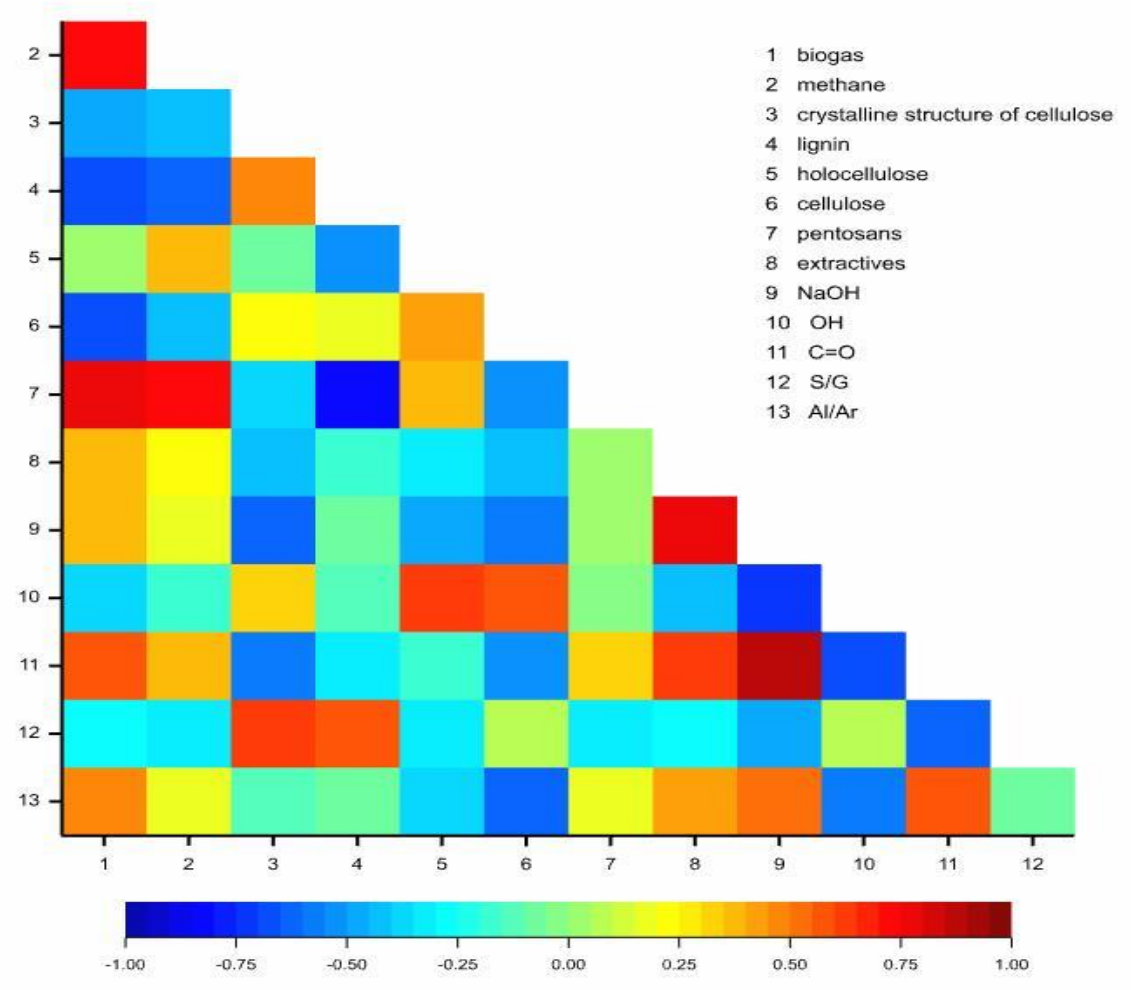

Fig. 1. Heatmap for the linear Pearson's correlation coefficients between the observed traits (red indicates a strong positive correlation and blue indicates a strong negative correlation) 
Table 5. Correlation Coefficients Between all Pairs of Observed Traits

\begin{tabular}{|c|c|c|c|c|c|c|c|c|c|c|c|c|}
\hline Trait & $\begin{array}{l}\text { Biogas } \\
\text { Yield }\end{array}$ & $\begin{array}{l}\text { Methane } \\
\text { Yield }\end{array}$ & $\begin{array}{l}\text { Crystalline } \\
\text { Structure of } \\
\text { Cellulose }\end{array}$ & Lignin & Holocellulose & Cellulose & Pentosans & Extractives & $\mathrm{NaOH}$ & $\mathrm{OH}$ & $\mathrm{C}=\mathrm{O}$ & $\begin{array}{l}\text { S to } G \\
\text { Ratio }\end{array}$ \\
\hline $\begin{array}{c}\text { Methane } \\
\text { Yield }\end{array}$ & $0.72^{* * *}$ & & & & & & & & & & & \\
\hline $\begin{array}{l}\text { Crystalline } \\
\text { Structure of } \\
\text { Cellulose }\end{array}$ & $-0.45^{\star \star \star}$ & $-0.45^{\star * *}$ & & & & & & & & & & \\
\hline Lignin & $-0.7^{\star \star \star}$ & $-0.64^{\star * *}$ & $0.46^{* * *}$ & & & & & & & & & \\
\hline Holocellulose & 0.04 & $0.37^{* \star \star}$ & -0.08 & $-0.55^{\star \star \star}$ & & & & & & & & \\
\hline Cellulose & $-0.68^{\star \star \star}$ & $-0.44^{\star \star \star}$ & 0.2 & 0.18 & $0.41^{\star * \star}$ & & & & & & & \\
\hline Pentosans & $0.8^{\star * \star}$ & $0.71^{* * *}$ & $-0.37^{* *}$ & $-0.82^{* \star *}$ & $0.37^{* *}$ & $-0.53^{\star * \star}$ & & & & & & \\
\hline Extractives & $0.36^{* *}$ & 0.22 & $-0.4^{* * *}$ & -0.18 & $-0.33^{* *}$ & $-0.44^{\star * *}$ & 0.05 & & & & & \\
\hline $\mathrm{NaOH}$ & $0.37^{* \star *}$ & 0.19 & $-0.6^{\star * *}$ & -0.05 & $-0.46^{\star \star *}$ & $-0.56^{\star \star *}$ & 0.05 & $0.77^{\star * \star}$ & & & & \\
\hline $\mathrm{OH}$ & $-0.39^{* * *}$ & -0.19 & $0.31^{* *}$ & -0.11 & $0.61^{* * *}$ & $0.6^{\star * *}$ & -0.03 & $-0.44^{* * *}$ & $-0.7^{\star \star \star}$ & & & \\
\hline $\mathrm{C}=\mathrm{O}$ & $0.56^{* * *}$ & $0.39^{\star \star \star}$ & $-0.57^{* * *}$ & $-0.33^{\star *}$ & -0.16 & $-0.54^{\star \star *}$ & $0.31^{* *}$ & $0.62^{* * *}$ & $0.86^{* * *}$ & $-0.66^{\star * \star}$ & & \\
\hline$S$ to $G$ Ratio & $-0.29^{*}$ & $-0.33^{\star *}$ & $0.61^{* * *}$ & $0.56^{* \star \star}$ & $-0.33^{\star *}$ & 0.07 & $-0.32^{\star *}$ & $-0.29^{*}$ & $-0.47^{* \star *}$ & 0.06 & $-0.65^{\star \star \star}$ & \\
\hline Al to Ar Ratio & $0.45^{\star \star *}$ & 0.16 & -0.1 & -0.07 & $-0.37^{* * *}$ & $-0.6^{* * *}$ & 0.2 & $0.44^{* * *}$ & $0.53^{* * \star}$ & $-0.55^{\star * *}$ & $0.59^{* * *}$ & -0.1 \\
\hline
\end{tabular}




\section{Relationship between Biogas and Methane and the Other Investigated Traits}

Using a multivariate regression analysis, an analysis of the relationship between biogas and methane yield and the other investigated features, i.e., the percentage of cellulose crystalline structure, lignin, holocellulose, cellulose, pentosans, extractives, substances soluble in a $1 \% \mathrm{NaOH}$ solution, $\mathrm{OH}$ groups, $\mathrm{C}=\mathrm{O}$ groups, and the ratios of $\mathrm{S}$ to $\mathrm{G}$ and $\mathrm{Al}$ to $\mathrm{Ar}$, was performed. Characteristics of the significant traits on biogas and methane are presented in Table 6 .

Table 6. Characteristics Significantly Affecting the Biogas and Methane Yield

\begin{tabular}{|c|c|c|c|c|}
\hline \multirow{2}{*}{ Parameter } & \multicolumn{2}{|c|}{ Biogas Yield $\left(y_{1}\right)$} & \multicolumn{2}{|c|}{ Methane Yield $\left(y_{2}\right)$} \\
\hline & Estimate & $t$-Statistic & Estimate & $t$-Statistic \\
\hline Constant & 1030 & $6.43^{\star * \star}$ & 108.1 & $3.32^{* *}$ \\
\hline Crystalline structure of cellulose $\left(x_{1}\right)$ & -4.87 & $-2.26^{*}$ & -1.281 & $-3.91^{\star \star *}$ \\
\hline Lignin $\left(x_{2}\right)$ & -16.30 & $-12.42^{\star \star *}$ & ns & \\
\hline Holocellulose $\left(x_{3}\right)$ & ns & & 1.357 & $6.94^{\star * \star}$ \\
\hline Cellulose $\left(x_{4}\right)$ & -7.72 & $-7.03^{\star \star \star}$ & -1.007 & $-6.86^{\star * *}$ \\
\hline Pentosans $\left(x_{5}\right)$ & ns & & ns & \\
\hline Extractives $\left(x_{6}\right)$ & -2.52 & $-2.05^{\star}$ & 0.561 & $2.64^{*}$ \\
\hline $\mathrm{NaOH}\left(x_{7}\right)$ & ns & & -0.493 & $-3.40^{* *}$ \\
\hline $\mathrm{OH}\left(x_{8}\right)$ & ns & & -33.77 & $-3.40^{* *}$ \\
\hline $\mathrm{C}=\mathrm{O}\left(x_{9}\right)$ & 215.2 & $4.26^{\star \star \star}$ & ns & \\
\hline$S$ to $\mathrm{G}$ ratio $\left(x_{10}\right)$ & 319.5 & $5.33^{\star * \star}$ & ns & \\
\hline Al to Ar ratio $\left(x_{11}\right)$ & ns & & ns & \\
\hline Percentage variance accounted & \multicolumn{2}{|c|}{$86.00 \%$} & \multicolumn{2}{|c|}{$68.00 \%$} \\
\hline ns - not significant & & & & \\
\hline
\end{tabular}

The biogas yield was positively determined by the $\mathrm{C}=\mathrm{O}$ content and the $\mathrm{S}$ to $\mathrm{G}$ ratio, and negatively determined by the crystalline structure of cellulose, lignin, cellulose, and extractives. These six independent traits accounted for $86.00 \%$ of the biogas variance. The methane yield was positively determined by other parameters, i.e., by the percentage of holocellulose and extractives as well as negatively determined by the cellulose content and its crystalline structure, percentage of substances soluble in a $1 \% \mathrm{NaOH}$ solution, and $\mathrm{OH}$ groups. These six independent traits accounted for $68.00 \%$ of methane variance.

The analysis showed that the methane yield depends on the content of holocellulose, extractives, and cellulose, the degree of cellulose structure order, the amount of substances soluble in a $1 \% \mathrm{NaOH}$ solution, and the $\mathrm{OH}$ group content. The regression equation developed by Amon et al. (2007) for maize silage shows that the methane yield depends on the nutrient content of the raw material, i.e., the crude protein, crude fat, cellulose, and hemicellulose contents. The model developed by Triolo et al. (2011) for energy crops, e.g., grass, maize, and straw, or animal manure shows that the lignin concentration is the strongest predictor of the biochemical potential of methane for all types 
of biomasses. However, Dandikas et al. (2014), on the basis of the feed analysis of various energy crops, found that the biogas yield was significantly negatively correlated with the percentage of lignins. They showed that statistically, apart from the amount of lignins, only the hemicellulose content seemed to be important in terms of the differences in biogas yield. According to Dandikas et al. (2014), the model of Triolo et al. (2011) indicated a stronger influence of lignins.

\section{CONCLUSIONS}

1. Both the biogas and methane yields were determined by six significantly influencing characteristics. For the yield of biogas, model (1) was obtained, shown in Eq. 2,

$y_{1}=1030-4.87 x_{1}-16.3 x_{2}-7.72 x_{4}-2.52 x_{6}+215.2 x_{9}+319.5 x_{10}$

2. For the yield of methane, model (2) was obtained, shown in Eq. 3, $y_{2}=108.1-1.281 x_{1}+1.357 x_{3}-1.007 x_{4}+0.561 x_{6}-0.493 x_{7}-33.77 x_{8}$

3. The correlations between the observed traits showed that the biogas and methane yield was strongly positively correlated with the pentosans content in the raw materials. However, the analysis of multi-traits did not confirm this correlation.

4. For evaluation of biogas potential of biomass, there is a need to use both the analysis of the correlation between the observed features and the analysis of multi-features.

5. Specific, independent traits of biomass accounted for $86 \%$ of the biogas variance and $68 \%$ of the methane variance.

The results presented supplement the missing knowledge showing the impact of the chemical properties of the lignocellulosic materials on the biogas yield. These results are of great practical importance and are important for the energy industry as well as for global and national climate policy.

\section{ACKNOWLEDGMENTS}

The work was financially supported by the Ministry of Science and Higher Education (Grant No. BIOSTRATEG2/298241/10/NCBR/2016 Intelligent systems for breeding and cultivation of wheat, maize and poplar for optimized biomass production, biofuels and modified wood).

\section{REFERENCES CITED}

Aftab, M. N., Iqbal, I., Riaz, F., Karadag, A., and Tabatabaei, M. (2018). "Different pretreatment methods of lignocellulosic biomass for use in biofuel production," in: Biomass for Bioenergy - Recent Trends and Future Challenges, A. E-F. Abomorha (ed.), IntechOpen Ltd., London, United Kingdom.

Amon, T., Amon, B., Kryvoruchko, V., Zollitsch, W., Mayer, K., and Gruber, L. (2007). 
"Biogas production from maize and dairy cattle manure - Influence of biomass composition on the methane yield," Agriculture, Ecosystems \& Environment 118(14), 173-182. DOI: 10.1016/j.agee.2006.05.007

Castro, F. B., Hotten, P. M., Ørskov, E. R., and Rebeller, M. (1994). "Inhibition of rumen microbes by compounds formed in the steam treatment of wheat straw," Bioresource Technology 50(1), 25-30. DOI: 10.1016/0960-8524(94)90216-X

Cheah, W. Y., Sankaran, R., Show, P. L., Ibrahim, T. N. B., Chew, K. W., Culaba, A., and Chang, J.-S. (2020). "Pretreatment methods for lignocellulosic biofuels production: current advances, challenges and future prospects," Biofuel Research Journal 25, 1115-1127. DOI: 10.18331/BRJ2020.7.1.4

Dandikas, V., Heuwinkel, H., Lichti, F., Drewes, J. E., and Koch, K. (2014). "Correlation between biogas yield and chemical composition of energy crops," Bioresources Technology 174, 316-320. DOI: 10.1016/j.biortech.2014.10.019

DIN 38414-8 (1985). "Bestimmung des Faulverhaltens Schlamm und Sedimente Deutsche Einheitsverfahren zur Wasser-, Abwasser- und Schlammuntersuchung; Schlamm und Sedimente (gruppe S); Bestimmung des Faulverhaltens (S 8) [German standard methods for the examination of water, waste water and sludge; sludge and sediments (group S); determination of the amenability to anaerobic digestion (S 8)]," German Institute for Standardization, Berlin, Germany.

Directive 2018/2001/EU: The Renewable Energy Directive, RED II

Fan, M., Dai, D., and Huang, B. (2012). "Fourier transform infrared spectroscopy for natural fibres," in: Fourier Transformation - Materials Analysis, S. Salih (ed.), IntechOpen Ltd., London, United Kingdom.

Hindeleh, A. M., and Johnson, D. J. (1971). "The resolution of multipeak data in fibre science," Journal of Physics D: Applied Physics 4(2), 259-263. DOI: 10.1088/0022$3727 / 4 / 2 / 311$

Kamusoko, R., Jingura, R. M., Parawira, W., and Sanyika, W.T. (2019). “Comparison of pretreatment methods that enhance biomethane production from crop residues - A systematic review," Biofuel Research Journal 24, 1080-1089. DOI: 10.18331/BRJ2019.6.4.4

Lewicki, A., Pilarski, K., Janczak, D., Czekała, W., Carmona, P. C. R., Cieślik, M., and Witaszek, K. (2013). "The biogas production from herbs and waste from herbal industry," Journal of Research and Applications in Agricultural Engineering 58(1), 114-117.

Lin, S. Y., and Dence, C. W. (1992). Methods in Lignin Chemistry, Springer, Berlin, Germany.

Michalska, K., and Ledakowicz, S. (2012). "Degradacja struktur lignocelulozowych oraz produktów ich hydrolizy [Degradation of lignocellulosic structures and products of their hydrolysis]," Inżynieria i Aparatura Chemiczna [Engineering and Chemical Equipment] 51(4), 157-159.

Mulat, D. G., Dibdiakova, J., and Horn, S. J. (2018). "Microbial biogas production from hydrolysis lignin: Insight into lignin structural changes," Biotechnology for Biofuels 11, 1-16. DOI: 10.1186/s13068-018-1054-7

Panahi, H. K. S., Dehhaghi, M., Kinder, J. E., and Ezeji, T. Ch. (2019). "A review on green liquid fuels for the transportation sector: A prospect of microbial solutions to climate change," Biofuel Research Journal 23, 995-1024. DOI:

10.18331/BRJ2019.6.3.2

PN EN 12879 (2002). “Charakterystyka osadów ściekowych - Oznaczanie strat przy 
prażeniu suchej masy [Characteristics of sewage sludge - Determination of losses on burning dry matter]," Polish Committee for Standardization, Warsaw, Poland.

PN EN ISO 9963-1 (2001). “Jakość wody - Oznaczanie zasadowości - Część 1:

Oznaczanie zasadowości ogólnej i zasadowości wobec fenoloftaleiny [Water quality Determination of alkalinity - Part 1: Determination of total alkalinity and alkalinity towards phenolphthalein] ( $\mathrm{pH})$," Polish Committee for Standardization, Warsaw, Poland.

PN-73/C-04576/02 (1973). "Woda i ścieki - Badania zawartości związków azotu Oznaczanie azotu amonowego metodą miareczkową [Water and sewage - Tests for the content of nitrogen compounds - Determination of ammoniacal nitrogen by titration]," Polish Committee for Standardization, Warsaw, Poland.

$\mathrm{Pu}, \mathrm{Y}$., Hu, F., Huang, F., Davison, B. H., and Ragauskas, A. J. (2013). "Assessing the molecular structure basis for biomass recalcitrance during dilute acid and hydrothermal pretreatments," Biotechnology for Biofuels 6, 1-13. DOI: 10.1186/17546834-6-15

Rabiej, S. (1991). "A comparison of two X-ray diffraction procedures for crystallinity determination," European Polymers Journal 27(9), 947-954. DOI: 10.1016/00143057(91)90038-P

Ragauskas, A. J., Beckham, G. T., Biddy, M. J., Chandra, R., Chen, F., Davis, M. F., Davison, B. H., Dixon, R. A., Gilna, P., et al. (2014). "Lignin valorization: Improving lignin processing in the biorefinery," Science 344(6185), 709-720. DOI: 10.1126/science. 1246843

Sandford, S. A., Bernstein, M. P., and Materese, C. K. (2013). "The infrared spectra of polycyclic aromatic hydrocarbons with excess peripheral $\mathrm{H}$ atoms $\left(\mathrm{H}_{\mathrm{n}} \mathrm{PAHs}\right)$ and their relation to the 3.4 and $6.9 \mu \mathrm{m}$ PAH emission features," The Astrophysical Journal Supplement Series 205(1), 1-30. DOI: 10.1088/0067-0049/205/1/8

Shapiro, S. S., and Wilk, M. B. (1965). "An analysis of variance test for normality (complete samples),” Biometrika 52(1965), 591-611. DOI: 10.1093/biomet/52.3-4.591

Stachowiak-Wencek, A., Zborowska, M., Waliszewska, H., and Waliszewska, B. (2018). "Zmiany struktury ligniny osadków kukurydzy pod wpływem fermentacji metanowej [Changes in the lignin structure of maize waste during methane fermentation]," Przemyst chemiczny [Chemical Industry] 97(12), 2162-2165. DOI: 10.15199/62.2018.12.30

Stachowiak-Wencek, A., Zborowska, M., Waliszewska, H., and Waliszewska, B. (2019a). "Chemical changes in lignocellulosic biomass (corncob) influenced by pretreatment and anaerobic digestion (AD)," BioResources 14(4), 8082-8099. DOI: 10.15376/biores.14.4.8082-8099

Stachowiak-Wencek, A., Zborowska, M., Walkowiak, M., Waliszewska, H., and Waliszewska, B. (2019b). "Utilization of post-fermentation maize waste by thermal conversion," Drewno [Wood] 62(204), 115-126. DOI: 10.12841/wood.16443985.289.01

Tabatabaei, M., Aghbashlo, M., Valijanian, E., Panahi, H. K. S., Nizami, A.-S., Ghanavati, H., Sulaiman, A., Mirmohamadsadeghi, S., and Karimi, K. (2020a). "A comprehensive review on recent biological innovations to improve biogas production, Part 1: Upstream strategies," Renewable Energy 146, 1204-1220, DOI: 10.1016/j.renene.2019.07.037

Tabatabaei, M., Aghbashlo, M., Valijanian, E., Panahi, H. K. S., Nizami, A.-S., Ghanavati, H., Sulaiman, A., Mirmohamadsadeghi, S., and Karimi, K. (2020b). “A 
comprehensive review on recent biological innovations to improve biogas production, Part 2: Mainstream and downstream strategies," Renewable Energy 146, 1392-1407. DOI: $10.1016 /$ j.renene.2019.07.047

TAPPI T 204 cm-07 (2007). "Solvent extractives of wood and pulp," TAPPI Press, Atlanta, GA.

TAPPI T 211 om-07 (2007). "Ash in wood, pulp, paper and paperboard: Combustion at $525{ }^{\circ} \mathrm{C}$," TAPPI Press, Atlanta, GA.

TAPPI T 212 om-07 (2007). "One percent sodium hydroxide solubility of wood and pulp," TAPPI Press, Atlanta, GA.

TAPPI T 222 om-06 (2006). “Acid insoluble lignin in wood and pulp,” TAPPI Press, Atlanta, GA.

TAPPI T 223 cm-01 (2001). "Pentosans in wood and pulp," TAPPI Press, Atlanta, GA.

TAPPI T9 wd-75 (2015). "Holocellulose in wood," TAPPI Press, Atlanta, GA.

Theuretzbacher, F., Lizasoain, J., Lefever, C., Saylor, M. K., Enguidanos, R., Weran, N., Gronauer, A., and Bauer, A. (2015). "Steam explosion pretreatment of wheat straw to improve methane yields: Investigation of the degradation kinetics of structural compounds during anaerobic digestion," Bioresource Technology 179, 299-305. DOI: 10.1016/j.biortech.2014.12.008

Thomsen, S. T., Spliid, H., and Østergård, H. (2014). "Statistical prediction of biomethane potentials based on the composition of lignocellulosic biomass," Bioresource Technology 154, 80-86. DOI: 10.1016/j.biortech.2013.12.029

Triolo, J. M., Sommer, S. G., Møller, H. B., Weisbjerg, M. R., and Jiang, X. Y. (2011). "A new algorithm to characterize biodegradability of biomass during anaerobic digestion: Influence of lignin concentration on methane production potential," Bioresource Technology 102(20), 9395-9402. DOI: 10.1016/j.biortech.2011.07.026,

Tursi, A. (2019). "A review on biomass: Importance, chemistry, classification, and conversion," Biofuel Research Journal 22, 962-979. DOI: 10.18331/BRJ2019.6.2.3

VDI 4630 (2016). "Fermentation of organic materials - Characterization of the substrate, sampling, collection of material data, fermentation tests," Verein Deutscher Ingenieure, Düsseldorf, Germany.

Waliszewska, H., Zborowska, M., Stachowiak-Wencek, A., Waliszewska, B., and Czekała, W. (2019). "Lignin transformation of one-year-old plants during anaerobic digestion (AD)," Polymers 11(5), 1-10. DOI: 10.3390/polym11050835.

Waliszewska, H., Zborowska, M., Waliszewska, B., Borysiak, S., Antczak, A., and Czekała, W. (2018). "Transformation of Miscanthus and Sorghum cellulose during methane fermentation," Cellulose 25(2), 1207-1216. DOI:10.1007/s10570-017-1622-1

Witaszek, K., Pilarska, A. A., and Pilarski, K. (2015). "Wybrane metody wstępnej obróbki surowców roślinnych stosowanych do produkcji biogazu [Selected methods of pre-treatment of plant raw materials used for biogas production]," Ekonomia $i$ Środowisko [Economics and Environment] 2(53), 130-144.

Zhang, Y., Liu, Z., Liu, H., Hui, L., Wang, H., and Liu, H. (2019). “Characterization of liquefied products from corn stalk and its biomass components by polyhydric alcohols with phosphoric acid," Carbohydrate Polymers 215, 170-178. DOI: 10.1016/j.carbpol.2019.03.096

Article submitted: August 4, 2021; Peer review completed: August 21, 2021; Revised version received and accepted: September 2, 2021; Published: September 7, 2021. DOI: $10.15376 /$ biores.16.4.7086-7100 